\title{
MUTACIONES DE LAS POLÍTICAS ANTE LAS NUEVAS PROBLEMÁTICAS SOCIALES. UN ESTUDIO DE CASO DE UNA AGENCIA DE EXTENSIÓN RURAL EN LA PROVINCIA DE SANTA FE
}

\author{
Cardozo, L. G. ${ }^{1}$
}

\begin{abstract}
RESUMEN
Desde la reestructuración del capitalismo a partir de los años 70s del siglo pasado se llevaron cabo modificaciones no sólo en el aspecto económico sino también en otras esferas de alcance de lo político, social y cultural. En el presente artículo se presenta las nuevas formas que asumen las políticas sociales a partir de la configuración del capitalismo y la nueva cuestión social. Diversos autores caracterizan a las políticas como políticas de workfare, inmersas en un proyecto global en constante mutación y reconversión para dar soluciones rápidas a las problemáticas locales. A partir de un caso de estudio de la Provincia de Santa Fe, analizaremos el rol de una agencia de Extensión Rural encargada de implementar políticas que sufren ciertas modificaciones en el contexto de las problemáticas sociales contemporáneas.

Palabras claves: política social, workfare, agencia de extensión rural, Santa Fe, Argentina.
\end{abstract}

\begin{abstract}
Mutations the policies to the new social problems. A case study of rural extension agency in the province of Santa Fe.

Since the restructuring of capitalism from the 70s of last century, modifications were carried out not only in economic terms but also in other areas of scope of the political, social and cultural. In this article the new forms taken by social policies from the configuration of capitalism and the new social question is presented. Several authors characterize policies as workfare policies immersed in a constantly changing global project and conversion to provide solutions to local problems. From a case study of the Province of Santa Fe, we discuss the role of Rural Extension Agency responsible of implementing policies that suffer some changes in the context of contemporary social problems. Key words: social policy rural, agency extension, workfare, Santa Fe, Argentina.
\end{abstract}

1.-Licenciado en Geografía. Maestrando en Economía Social, Universidad Nacional de Sarmiento. Programa de Economía Social y Solidaria de la Secretaría de Extensión, Universidad Nacional del Litoral. Email: lcardozo@fce.unl.edu.ar

Manuscrito recibido el 4 de febrero de 2016 y aceptado para su publicación el 4 de junio de 2016. 